\title{
Health Education for preschool children in daycare centers
}

\author{
Elsa Carolina Rojas-Ortiz, Vidal E. Álvarez-Rodríguez, Hilda Gabriela León-Suazo, \\ Arturo Baños-Sánchez, Patricia Trejo-Morales and Demetrio Arturo Bernal-Alcántara* \\ Western Zone Regional Delegation, Instituto de Seguridad y Servicios Sociales de los Trabajadores del Estado, City of Mexico, Mexico
}

\begin{abstract}
Background: The promotion of health is carried out in preventive services of medical units, in educational programs and textbooks from the general perspective of the population. Objective: To determine baseline characteristics of health education for pre-school children, their parents and teachers, by means of specialist doctors. Method: Cross-sectional study of an educational program for preschool children. Life skills and health competencies were evaluated. Results: The preschoolers developed resilience (84.12\%), empathy (92.23\%), assertive communication (93.5\%), interpersonal relationships (91.0\%), correct decision making (92.56\%), problem solving (81.05\%), creative thinking (98\%), critical thinking (86.08\%), emotion management (80.76\%), physical activation (97.94\%), self-knowledge (98.96\%), hygienic habits (94.90\%) and co-responsibility (86.25\%); 95.59\% liked the workshop and $95.75 \%$ chose the correct option in the problems described. $63.04 \%$ of parents generated changes in their habits and those of their children. Conclusion: The educational program implemented can promote empowerment in health from childhood.
\end{abstract}

KEY WORDS: Preschoolers. Health promotion. Resilience.

\section{Introduction}

Family, school and health systems act as protective factors if the individual finds in them security, support and information that allows him/her making decisions that benefit his/her quality of life ${ }^{1,2}$; however, this is not happening in contemporary society, which is considered to be of risk ${ }^{3}$.

Mexico is within the top five places in childhood overweight and obesity and occupies the second place in the case of adults ${ }^{4}$, which represents a risk factor, since it reduces life expectancy and quality by producing conditions such as diabetes, hypertension, dyslipidemia and psychological problems ${ }^{5}$. Globally, anorexia and bulimia are among the eating disorders with an upward trend ${ }^{6}$.

Currently, Mexico occupies the first place in adolescent pregnancy according to the Organization for Economic Cooperation and Development and, according to the 2014 National Survey of Demographic Dynamics, one out of every three female adolescents in the 15 to 19 years age group has already initiated her sexual life, and of that total, more than $40 \%$ did not use any contraceptive method on their first sexual intercourse, which is considered a risky behavior that can affect their life project ${ }^{7,8}$. In addition, Mexico occupies the first place in sexual abuse and physical violence against children and, despite the existence of intervention guidelines and some prevention programs, there is still a lot of work to be done $e^{9,10}$.

Emotion management is one of the basic aspects that guarantee health; however, some children and adolescents have difficulties to achieve it, and develop self-injurious behaviors, depression, anxiety, stress or addictions..$^{11,12}$.

Depression is a mental disorder that affects familiar, school, work and social performance of the person suffering from it and its appearance at early ages is considered a risk factor for comorbidity in adulthood ${ }^{13-15}$.

Currently, self-inflicted lesions are found within the first three causes of mortality in the 15 to 24-year age group, which represents more than half of total deaths in this group ${ }^{16}$.
Correspondence:

*Demetrio Arturo Bernal Alcántara

E-mail: demetrio.bernal@issste.gob.mx
Date of reception: 06-03-2019

Date of acceptance: 19-03-2019

DOI: 10.24875/GMM.M19000286
Gac Med Mex. 2019;155 (Suppl 1):S28-S34

Contents available at PubMed www.gacetamedicademexico.com 
Family and school dynamics are affected by the consumption of substances that are harmful to health such as tobacco, alcohol or drugs (marijuana, inhalants, tranquilizers and cocaine), which occurs since early ages ${ }^{17-19}$, as well as by bullying at school, which affects the physical and emotional health of aggressors, victims and spectators ${ }^{20}$. Another variable that affects this dynamic is inappropriate handling of children and young people with attention deficit hyperactivity disorder, since it represents one of the most common reasons for consultation in the specialty of pediatric psychiatry ${ }^{21}$ and is estimated to have an approximate prevalence of $5 \%^{22}$. In view of this epidemiological panorama, those responsible for health require to promote preventive programs that allow the development of healthy behaviors and habits since childhood in order to avoid risky behaviors throughout life. With the purpose to contribute to the control and prevention of chronic diseases and decrease some social problems, the ISSSTE in your School program was created (by the Institute of Social Security and Services of State Workers), which has resilience as its guiding axis. Resilience is the ability of human beings to face adversities and overcoming them, resurfacing, adapting and rebuilding themselves in order to foster successful psychological and social development $^{23,24}$. Being a dynamic process, it can be taught at any moment of the life cycle to achieve a balance between individual personality, risk factors and protecting factors ${ }^{25,26}$. For all the above, the purpose of this investigation was to determine the baseline characteristics of the Proactive Health Model by training girls, boys, parents and teachers in order to generate competences for health and skills for life and thus strengthen the health-education binomial.

\section{Method}

Cross-sectional study with non-probabilistic intentional sampling carried out at the Children's Wellness and Development Daycare Centers (EBDI - Estancias de Bienestar y Desarrollo Infantil) of the ISSSTE Western Regional Delegation during the 2016-2017 Schoolyear. Ludic-experiential workshops were carried out with parents, teachers, students and Preschool 2 and 3 children. All participants signed the Informed Consent Letter; in addition, parents gave their written authorization in order for their children to participate in the workshops. The research protocol was approved by the Ethics and Research Committee. Attendance of the children who were trained in each of the thematic axes varied depending on the day each workshop took place on (range: 205 to 239). Of the total sample, $52.77 \%$ were girls and $47.23 \%$ were boys.

Those responsible for each thematic axis applied a survey to girls and boys where, in an individual manner, they expressed their degree of satisfaction and solved a problem that allowed measuring their ability to apply the knowledge acquired in the workshop. In the Nutrition Survey, some parental habits such as food consumption and exercise were measured. In the Questionnaire for Parents, they were asked to issue a dichotomous answer on whether their children had acquired or not the listed skills after having attended the workshops.

In a first session, the parents and teachers were explained the purpose of the ISSSTE in your School Program, the benefits they would obtain should they participate and were given the Letter of Consent for signature. Based on the Ministry of Public Education calendar, a schedule was prepared in order for the multidisciplinary team, made up of medical specialists, nurses, social workers, nutritionists, psychologists and physical activators, to attend the eight Western Delegation EBDIs, one EBDI per month.

In the first week the girls and boys were trained, in the second, the parents and in the third one, the EBDI human capital. One thematic axis was addressed by day and the order whereby the workshops were carried out was: 1) Resilience, 2) Healthy nutrition since childhood, 3) Mental and emotional health, 4) Knowing and taking care of my body and 5) Social skills. The purpose of each axis, as well as some of the topics that were reviewed in each of them, are presented in Table 1. Audiovisual and support material, specifically-created for each of the recreational-experiential workshops was used. In the case of girls and boys, the surveys were applied at the end of each workshop, whereas in the case of the parents, it was done at the end of the week.

Descriptive statistics were used and the percentages obtained for the items listed both in the Questionnaire for Parents and in the Nutrition Survey are reported. In addition, the degree of satisfaction and the choice for each problem of the Survey for Girls and Boys applied at each workshop were also described.

\section{Results}

Table 2 shows the number and percentage of girls and boys for each EBDI with regard to the degree of 
Table 1. Thematic axes of the ISSSTE in your School Program, topics and activities

\begin{tabular}{|c|c|c|c|c|}
\hline \multicolumn{2}{|c|}{ Thematic Axis } & \multirow{2}{*}{$\begin{array}{l}\text { Objective } \\
\text { To provide tools and skills for life } \\
\text { that promote a resilient behavior to } \\
\text { face the challenges of the future }\end{array}$} & \multirow{2}{*}{$\begin{array}{l}\text { Topics } \\
\text { Resilience, self-esteem, work } \\
\text { environment, decision making, } \\
\text { inclusion and creative thinking }\end{array}$} & \multirow{2}{*}{$\begin{array}{l}\text { Activities } \\
\text { Club, first aid kit and little resilient house, } \\
\text { art and resilience and the color of my } \\
\text { adversity }\end{array}$} \\
\hline I & Resilience & & & \\
\hline$\|$ & $\begin{array}{l}\text { Healthy nutrition } \\
\text { since childhood }\end{array}$ & $\begin{array}{l}\text { To provide the necessary } \\
\text { knowledge and skills for making } \\
\text { correct decisions related to food } \\
\text { and physical activity }\end{array}$ & $\begin{array}{l}\text { Overweight and obesity, healthy } \\
\text { eating plate, healthy beverage } \\
\text { pitcher, healthy lunch, unhealthy } \\
\text { food, anorexia and bulimia and } \\
\text { physical activity }\end{array}$ & $\begin{array}{l}\text { Marian's story, Jeopardy, } \\
\text { health triangle, resilient bicycle, } \\
\text { preparation of healthy menus } \\
\text { and physical exercises }\end{array}$ \\
\hline III & $\begin{array}{l}\text { Mental and } \\
\text { emotional health }\end{array}$ & $\begin{array}{l}\text { Acquisition of skills for control and } \\
\text { management of emotions that } \\
\text { allow confronting adversities and } \\
\text { prevent diseases }\end{array}$ & $\begin{array}{l}\text { Identification, control and } \\
\text { management of emotions, } \\
\text { depression, suicide, self-esteem, } \\
\text { attention deficit disorder and bullying }\end{array}$ & $\begin{array}{l}\text { Traffic light, panel of emotions, } \\
\text { fear-eating monster, faint-hearted } \\
\text { squirrel, body expression and laughter } \\
\text { therapy }\end{array}$ \\
\hline IV & $\begin{array}{l}\text { Knowing and } \\
\text { taking care of my } \\
\text { body }\end{array}$ & $\begin{array}{l}\text { To teach skills that favor correct } \\
\text { decision making for a proper, risk } \\
\text { free sex life that does not affect } \\
\text { their life project }\end{array}$ & $\begin{array}{l}\text { Life cycle, hygienic habits, } \\
\text { pregnancy and sexual abuse } \\
\text { prevention }\end{array}$ & $\begin{array}{l}\text { Body parts identifying, story teller, } \\
\text { hygienic habits, Kiko's hand and puppet } \\
\text { show }\end{array}$ \\
\hline V & Social skills & $\begin{array}{l}\text { To learn skills and competences } \\
\text { to adopt a healthy lifestyle and } \\
\text { improve communication in the } \\
\text { family }\end{array}$ & $\begin{array}{l}\text { Concept and types of family, } \\
\text { communication, the five languages } \\
\text { of love, values, rules and limits, } \\
\text { inclusion, prevention of accidents } \\
\text { and good manners }\end{array}$ & $\begin{array}{l}\text { Professions and trades, universal values, } \\
\text { prevention of accidents, emergency first } \\
\text { aid kit, good manners, communication } \\
\text { strategies and management of limits }\end{array}$ \\
\hline
\end{tabular}

Table 2. Girls and boys trained in each thematic axis at the Children's Wellness and Development Daycare Centers (EBDI)

\begin{tabular}{|c|c|c|c|c|c|c|c|c|c|c|c|c|c|c|c|}
\hline \multirow[t]{3}{*}{ EBDI } & \multicolumn{15}{|c|}{ Axes } \\
\hline & \multicolumn{3}{|c|}{$\begin{array}{c}\mathrm{I} \\
(\mathrm{n}=205)\end{array}$} & \multicolumn{3}{|c|}{$\begin{array}{c}\text { II } \\
(\mathrm{n}=239)\end{array}$} & \multicolumn{3}{|c|}{$\begin{array}{c}\text { III } \\
(n=232)\end{array}$} & \multicolumn{3}{|c|}{$\begin{array}{c}\text { IV } \\
(n=233)\end{array}$} & \multicolumn{3}{|c|}{$\begin{array}{c}V \\
(n=231)\end{array}$} \\
\hline & Total & \begin{tabular}{|l|} 
Liking \\
n (\%)
\end{tabular} & $\begin{array}{c}\text { Decision } \\
n(\%)\end{array}$ & Total & \begin{tabular}{|l} 
Liking \\
n (\%)
\end{tabular} & $\begin{array}{c}\text { Decision } \\
n(\%)\end{array}$ & Total & $\begin{array}{l}\text { Liking } \\
\text { n (\%) }\end{array}$ & $\begin{array}{c}\text { Decision } \\
\text { n (\%) }\end{array}$ & Total & \begin{tabular}{|l|} 
Liking \\
n (\%)
\end{tabular} & $\begin{array}{c}\text { Decision } \\
n(\%)\end{array}$ & Total & $\begin{array}{l}\text { Liking } \\
\text { n (\%) }\end{array}$ & $\begin{array}{c}\text { Decision } \\
n(\%)\end{array}$ \\
\hline 16 & 35 & $\begin{array}{c}34 \\
(97.14)\end{array}$ & $\begin{array}{c}34 \\
(97.14)\end{array}$ & 31 & $\begin{array}{c}30 \\
(96.77)\end{array}$ & $\begin{array}{c}30 \\
(96.77)\end{array}$ & 30 & $\begin{array}{c}29 \\
(96.67)\end{array}$ & $\begin{array}{c}29 \\
(96.67)\end{array}$ & 32 & $\begin{array}{c}31 \\
(96.88)\end{array}$ & $\begin{array}{c}31 \\
(96.88)\end{array}$ & 28 & $\begin{array}{c}27 \\
(96.43)\end{array}$ & $\begin{array}{c}27 \\
(96.43)\end{array}$ \\
\hline 27 & 16 & $\begin{array}{c}11 \\
(68.75)\end{array}$ & $\begin{array}{c}16 \\
(100)\end{array}$ & 16 & $\begin{array}{c}16 \\
(100)\end{array}$ & $\begin{array}{c}14 \\
(87.50)\end{array}$ & 15 & $\begin{array}{c}14 \\
(93.33)\end{array}$ & $\begin{array}{c}14 \\
(93.33)\end{array}$ & 16 & $\begin{array}{c}15 \\
(93.75)\end{array}$ & $\begin{array}{c}15 \\
(93.75)\end{array}$ & 18 & $\begin{array}{c}17 \\
(94.44)\end{array}$ & $\begin{array}{c}17 \\
(94.44)\end{array}$ \\
\hline 41 & 21 & $\begin{array}{c}21 \\
(100)\end{array}$ & $\begin{array}{c}18 \\
(85.71)\end{array}$ & 40 & $\begin{array}{c}38 \\
(95)\end{array}$ & $\begin{array}{c}38 \\
(95)\end{array}$ & 44 & $\begin{array}{c}40 \\
(90.91)\end{array}$ & $\begin{array}{c}40 \\
(90.91)\end{array}$ & 49 & $\begin{array}{c}49 \\
(100)\end{array}$ & $\begin{array}{c}47 \\
(95.92)\end{array}$ & 40 & $\begin{array}{c}40 \\
(100)\end{array}$ & $\begin{array}{c}39 \\
(97.50)\end{array}$ \\
\hline 46 & 17 & $\begin{array}{c}16 \\
(94.12)\end{array}$ & $\begin{array}{c}17 \\
(100)\end{array}$ & 19 & $\begin{array}{c}19 \\
(100)\end{array}$ & $\begin{array}{c}19 \\
(100)\end{array}$ & 20 & $\begin{array}{c}18 \\
(90)\end{array}$ & $\begin{array}{c}18 \\
(90)\end{array}$ & 13 & $\begin{array}{c}12 \\
(92.31)\end{array}$ & $\begin{array}{c}13 \\
(100)\end{array}$ & 20 & $\begin{array}{c}20 \\
(100)\end{array}$ & $\begin{array}{c}19 \\
(95)\end{array}$ \\
\hline 55 & 36 & $\begin{array}{c}34 \\
(94.44)\end{array}$ & $\begin{array}{c}34 \\
(94.44)\end{array}$ & 38 & $\begin{array}{c}37 \\
(97.37)\end{array}$ & $\begin{array}{c}36 \\
(94.74)\end{array}$ & 40 & $\begin{array}{c}39 \\
(97.50)\end{array}$ & $\begin{array}{c}39 \\
(97.50)\end{array}$ & 37 & $\begin{array}{c}37 \\
(100)\end{array}$ & $\begin{array}{c}37 \\
(100)\end{array}$ & 38 & $\begin{array}{c}36 \\
(94.74)\end{array}$ & $\begin{array}{c}36 \\
(94.74)\end{array}$ \\
\hline 135 & 30 & $\begin{array}{c}27 \\
(90)\end{array}$ & $\begin{array}{c}30 \\
(100)\end{array}$ & 35 & $\begin{array}{c}32 \\
(91.43)\end{array}$ & $\begin{array}{c}33 \\
(94.29)\end{array}$ & 28 & $\begin{array}{c}27 \\
(96.43)\end{array}$ & $\begin{array}{c}27 \\
(96.43)\end{array}$ & 29 & $\begin{array}{c}28 \\
(96.55)\end{array}$ & $\begin{array}{c}28 \\
(96.55)\end{array}$ & 34 & $\begin{array}{c}33 \\
(97.06)\end{array}$ & $\begin{array}{c}32 \\
(94.12)\end{array}$ \\
\hline 155 & 27 & $\begin{array}{c}25 \\
(92.59)\end{array}$ & $\begin{array}{c}26 \\
(96.30)\end{array}$ & 30 & $\begin{array}{c}30 \\
(100)\end{array}$ & $\begin{array}{c}29 \\
(96.67)\end{array}$ & 30 & $\begin{array}{c}28 \\
(93.33)\end{array}$ & $\begin{array}{l}27 \\
(90)\end{array}$ & 29 & $\begin{array}{c}26 \\
(89.66)\end{array}$ & $\begin{array}{c}27 \\
(93.10)\end{array}$ & 27 & $\begin{array}{c}27 \\
(100)\end{array}$ & $\begin{array}{c}27 \\
(100)\end{array}$ \\
\hline 156 & 23 & $\begin{array}{c}23 \\
(100)\end{array}$ & $\begin{array}{c}22 \\
(95.65)\end{array}$ & 30 & $\begin{array}{c}30 \\
(100)\end{array}$ & $\begin{array}{c}29 \\
(96.67)\end{array}$ & 25 & $\begin{array}{l}24 \\
(96)\end{array}$ & $\begin{array}{l}24 \\
(96)\end{array}$ & 28 & $\begin{array}{c}28 \\
(100)\end{array}$ & $\begin{array}{c}28 \\
(100)\end{array}$ & 26 & $\begin{array}{c}26 \\
(100)\end{array}$ & $\begin{array}{c}26 \\
(100)\end{array}$ \\
\hline
\end{tabular}

Axes: I (Resilience), II (Healthy nutrition since childhood), III (Mental and emotional health), IV (Knowing and taking care of my body) and V (Social skills). Total refers to the number of girls and boys trained at each EBDI; the Liking column indicates if they reported having liked the workshop and in the Decision column, if they correctly chose the healthiest behavior at the end of each workshop.

satisfaction and the correct choice at each one of the thematic axes. When the degree of satisfaction obtained for the axes was averaged, 95.59\% (SD: 2.40) of girls and boys were found to have liked the workshop; in addition, $95.75 \%$ (SD: 1.25) chose the correct option to the problem posed at the end of each survey. 
Table 3. Family members habits after the training received in the "healthy eating since childhood" axis at each one of the Children's Wellness and Development Daycare Centers (EBDI)

\begin{tabular}{|c|c|c|c|c|c|c|c|c|}
\hline \multirow[t]{2}{*}{ EBDI } & \multirow{2}{*}{$\begin{array}{c}\text { Practices } \\
\text { exercise (\%) }\end{array}$} & \multirow{2}{*}{$\begin{array}{l}\text { Changed } \\
\text { habits (\%) }\end{array}$} & \multicolumn{5}{|c|}{ Consumes (\%) } & \multirow{2}{*}{$\begin{array}{l}\text { Daily consumption of } \\
\text { soft drinks (average) }\end{array}$} \\
\hline & & & Vegetables & Fruits & Meat & Grains & Soft drinks & \\
\hline 16 & 52.74 & 65.07 & 95.89 & 96.58 & 90.41 & 80.82 & 45.89 & 1.7 \\
\hline 27 & 15.84 & 34.65 & 97.03 & 97.03 & 92.08 & 86.14 & 39.60 & 1.5 \\
\hline 41 & 42.59 & 62.22 & 95.93 & 98.52 & 94.07 & 80.37 & 42.22 & 1.5 \\
\hline 46 & 14.29 & 30.52 & 97.40 & 95.45 & 98.05 & 78.57 & 42.21 & 1.6 \\
\hline 55 & 35.96 & 71.91 & 97.75 & 95.51 & 94.38 & 78.65 & 33.71 & 1 \\
\hline 135 & 46.88 & 77.34 & 96.88 & 95.31 & 96.88 & 78.13 & 46.09 & 1.6 \\
\hline 155 & 36.00 & 86.67 & 97.33 & 89.33 & 93.33 & 81.33 & 45.33 & 1.2 \\
\hline 156 & 45.37 & 75.93 & 96.30 & 97.22 & 98.15 & 75.00 & 37.96 & 1.4 \\
\hline
\end{tabular}

In the Nutrition Survey applied to parents (Table 3), $96.81 \%$ (SD: 0.70 ) of total sample were found to consume vegetables, $95.62 \%$ (SD: 2.77 ) ingest fruits, 94.67\% (SD: 2.82) eat meat and 79.88\% (SD: 3.22) include grains in their diet. With regard to soft drinks, $41.63 \%$ (SD: 4.36 ) was found to include them in their diet, with average consumption being 1.44 glasses (SD: 0.23$)$. In addition, only $36.21 \%$ (SD: 14.18$)$ was found to practice some type of exercise and $63.04 \%$ (SD: 20.27) generated a change of habits after the workshop

In the Questionnaire for Parents (Table 4), parents reported that their children did develop the following skills and habits: resilience (mean \pm standard deviation: $84.51 \pm 8.88 \%)$, empathy $(92.29 \pm 4.22 \%)$, assertive communication $(93.54 \pm 5.54 \%)$, personal relationships $(91.07 \pm 4.58 \%)$, decision making (92.56 \pm $5.83 \%)$, problem solving $(81.05 \pm 12.60 \%)$, creative thinking $(98.06 \pm 2.59 \%)$, critical thinking $(86.09 \pm$ $9.34 \%)$, emotion management $(80.76 \pm 11.47 \%)$, physical activity $(97.95 \pm 2.41 \%)$, self-knowledge (98.96 \pm $2.22 \%)$, hygienic habits $(94.90 \pm 5.34 \%)$ and co-responsibility $(86.25 \pm 9.84 \%)$.

\section{Discussion}

The enthusiasm caused by the positive aspects the multidisciplinary team observed in this experience and the conviction of family members themselves and teachers who participated in the development of the workshops is encouraging; although the experience was brief and the sample small, the results allow us to glimpse the potential of this methodology. In the evaluation of girls and boys, $95.59 \%$ of satisfaction regarding the workshops and $95.79 \%$ of correct answers in written problems were obtained at the end of each survey; together, these results allow us to assume that systematization and continuous application of this experience will enable the attendees to acquire more tools to decide about their health and improve their skills for life.

This study represents a first approach to the strengthening of the health-education binomial, and it encompasses both the individual and the family and school spheres. The family is the structure of society that is responsible of its members' health, and the procedures for its preservation, promotion and recovery are therein generated ${ }^{27}$; therefore, its strengthening becomes a priority of health systems.

Intervention on preschoolers was decided because it is in childhood that the rules and values are learned; in addition, it is the period wherein role models are imitated (family or teachers), roles are rehearsed, self-concept is formed and emotion management, prosocial behaviors and communication and negotiation skills are learned ${ }^{28-30}$. Thus, teaching and strengthening some of the cornerstones of resilience (self-esteem, introspection, independence, ability to relate, critical thinking, initiative, sense of humor, creativity, morality) and skills for life (self-knowledge, empathy, assertive communication, personal relationships, decision making, creative and critical thinking, management of problems, conflicts, emotions, feelings and stress) ${ }^{31}$ allowed to improve the climate of familiar and school coexistence. Self-confidence, self-esteem, self-assurance, the ability to share and love, and even intellectual and social skills, have their roots in experiences lived during early childhood in the family and school bosom. A violent society, family dysfunction, negligent or authoritative parenting styles, or unclear 
Table 4. Parental report about the skills acquired by their children by the end of the 2016-2017 schoolyear

\begin{tabular}{|c|c|c|c|c|c|c|c|c|}
\hline \multirow[t]{2}{*}{ Competences } & \multicolumn{8}{|c|}{ EBDI } \\
\hline & $16(\%)$ & $27(\%)$ & $41(\%)$ & $46(\%)$ & $55(\%)$ & $135(\%)$ & $155(\%)$ & $156(\%)$ \\
\hline Resilience & 97.22 & 87.50 & 92.86 & 67.35 & 84.09 & 81.25 & 82.14 & 83.67 \\
\hline Empathy & 97.22 & 93.75 & 90.48 & 95.92 & 95.45 & 84.38 & 89.29 & 91.84 \\
\hline Assertive communication & 97.22 & 100 & 95.24 & 87.76 & 97.73 & 96.88 & 85.71 & 87.76 \\
\hline Personal relationships & 97.22 & 87.50 & 90.48 & 85.71 & 93.18 & 96.88 & 85.71 & 91.84 \\
\hline Decision making & 94.44 & 81.25 & 92.86 & 91.84 & 95.45 & 96.88 & 100 & 87.76 \\
\hline Problem solving & 91.67 & 81.25 & 83.33 & 53.06 & 86.36 & 84.38 & 92.86 & 75.51 \\
\hline Creative thinking & 100 & 100 & 100 & 97.96 & 97.73 & 100 & 92.86 & 95.92 \\
\hline Critical thinking & 91.67 & 81.25 & 83.33 & 67.35 & 95.45 & 87.50 & 96.43 & 85.71 \\
\hline Emotion management & 88.89 & 93.75 & 78.57 & 61.22 & 79.55 & 87.50 & 89.29 & 67.35 \\
\hline Physical activation & 94.44 & 100 & 95.24 & 97.96 & 100 & 100 & 100 & 95.92 \\
\hline Self-knowledge & 100 & 93.75 & 100 & 100 & 100 & 100 & 100 & 97.96 \\
\hline Hygienic habits & 97.22 & 93.75 & 100 & 83.67 & 100 & 93.75 & 92.86 & 97.96 \\
\hline Co-responsibility & 91.67 & 81.25 & 95.24 & 67.35 & 95.45 & 93.75 & 85.71 & 79.59 \\
\hline
\end{tabular}

EBDI (Estancia de Bienestar y Desarrollo Infanti): Children's Wellness and Development Daycare Centers.

rules at home, lack of communication or poor supervision and accompaniment of children, can generate psychological problems, addictions, violence or desensitization to violence ${ }^{32-35}$. In the study, a joint responsibility of teachers and parents was observed in preschool children's physical and mental health, not only due to their attendance to the Program, but to their active participation, since $63.04 \%$ reported having generated a change in their habits after attending the workshops. In places where an environment of love, respect, trust and stability is breathed, children thrive and develop psychically healthier and safer, and will relate similarly to the outside and with a more positive and constructive attitude towards life ${ }^{36}$.

This study is inserted in the concept of health promotion, which is the process that allows people increase control over their health and improve it, and encompasses both actions aimed at increasing people's skills and abilities, such as those intended to modify social, environmental and economic conditions in order for it to be improved. Health education is a part of the healthcare process that includes prevention, treatment and rehabilitation; therefore, it comprises learning opportunities aimed at improving health literacy by including an informed population with personal skills that lead to making conscious decisions that improve their quality of life. Educating in matters of health is a process whose purpose is to generate citizens who take responsibility in the defense of personal and collective health and, therefore, it is part of the functions of health, social and education professionals ${ }^{37}$. Although this study represents a first approach to the health-education binomial at the EBDIs, it can be observed that, in future interventions, programs will have to be strengthened in order to generate greater awareness in the participants and modify some habits. For example, only $36.21 \%$ of the sample practice any type of exercise, and $41.63 \%$ consume some soft drink; both behaviors favor the onset of overweight and obesity, which is considered a risk factor for the development of chronic non-communicable diseases.

The ISSSTE in your School Program is consistent with the proposals of the Schools for Health in Europe Network based on the experience developed by its predecessor, the European Network of Health-Promoting Schools ${ }^{38}$. This has facilitated strategic work between the education and health sectors, which has raised the profile and commitment with health promotion at school ${ }^{39,40}$. The Program recognizes the United Nations Convention on the Rights of the Child ${ }^{41,42}$ and promotes actions to raise the quality of education and health. The literature review ${ }^{43-46}$ and the examination of different ecological models ${ }^{46}$, supports the effectiveness of the schools for health approach, as well as its impact at a societal level. 


\section{Conclusion}

The ISSSTE in your School Program shows that there is an incalculable potential for the development of resilient, participatory and supportive children, parents and teachers that can empower themselves with regard to their health. This experience is intended as a contribution to that development, and as such, we consider it can be successful. This program is a contribution to the path of collaboration between the different responsible sectors in order for our society to have a life with better quality in terms of health. We consider the desirability of the trans-sexennial application of this type of work and that it should be carried out at all educational levels, since this would guarantee a greater impact on its results in the short, medium and long-term.

\section{Acknowledgements}

To the ISSSTE in your School multidisciplinary team and the staff of the Children's Wellness and Development Daycare Centers of the ISSSTE Western Regional Delegation for their collaboration and support in the development of this work.

\section{References}

1. FUNDADEPS. La familia como agente de salud. 1. ${ }^{\text {a }}$ Ed. Madrid: IO Sistemas de Comunicación; 2012.

2. Munist $M$, Santos $H$, Kotliarenco $M$, Suárez Ojeda $E$, Infante $F$, Grotberg E. Manual de identificación y promoción de la resiliencia en niños y adolescentes. Washington, D.C.: Fundación WK Kellog; 1998.

3. Munist M, Suárez Ojeda N, Krauskopf D, Silber T. Adolescencia y resilencia. México: Paidos, 2007.

4. Better policies for better lives [Internet]. Organisation for Economic Co-operation and Development; 2011. Disponible en: https://wwwoecdorg/about/47747755pdf

5. Barrera-Cruz A, Rodríguez-González A, Molina-Ayala MA. Escenario actual de la obesidad en México. Rev Med Inst Mex Seguro Soc. 2013;51:292-9.

6. Barriguete-Meléndez JA, Unikel-Santoncini C, Aguilar-Salinas C, Córdoba-Villalobos JA, Shamah T, Barquera S, et al. Prevalence of abnorma eating behaviors in adolescents in Mexico: Mexican National Health and Nutrition Survey 2006. Salud Publica Mex. 2009;51(Suppl 4):S638-44.

7. INEGI. Encuesta Nacional de la Dinámica Demográfica 2014 [Internet]. INEGI; 2014. Disponible en: http://wwwinegiorgmx/saladeprensa/boletines/2015/especiales/especiales2015_07_1pdf

8. Cancino AMM, Valencia MH. Embarazo en la adolescencia: cómo ocurre en la sociedad actual. Perinatol Reprod Hum. 2015;29:76-82.

9. Orientaciones para la prevención, detección y actuación en casos de abuso sexual infantil, acoso escolar y maltrato en las escuelas de Educación Básica [Internet]. México: Secretaría de Educación Pública; fecha documento [fecha de consulta o de última actualización]. Disponible en: www.gob.mx/cms/uploads/docs/Orientaciones_211216.pdf

10. Fatima Kantun Puc L, Peña Castillo RF. Prevención del abuso sexual en una comunidad maya de Yucatán, México: relevancia de las características socioculturales (2014). Rev Crim. 2015;57:74-90.

11. Albores-Gallo L. Autolesiones sin intención suicida en una muestra de niños y adolescentes de la ciudad de México. Actas Esp Psiquiatr. 2014:42(4):159-68.

12. Encuesta Nacional de Consumo de Drogas, Alcohol y Tabaco 2016 2017. México: Pública INdS. Disponible en: wwwinspmx/avisos/4585-encodat-2016htm

13. Sánchez-Hernández, Ó., Méndez, F., \& Garber, J. (2014). Prevención de la depresión en niños y adolescentes: Revisión y reflexión. Revista de Psicopatología y Psicología Clínica, 19(1), 63-76.
14. Garibay-Ramirez J, Jiménez-Garcés C, Vieyra-Reyes P, Hernández-González MM, Villalón-López J. Disfunción familiar y depresión en niños de 8-12 años de edad. Rev med investig Univ Autón Estado Méx. 2014;2:107-11.

15. Acosta-Hernández M, Mancilla-Percino $T$, Correa-Basurto J, Saavedra-Vélez M, Ramos-Morales F, Cruz-Sánchez JS, et al. Depresión en la infancia y adolescencia: enfermedad de nuestro tiempo. Archivos de neurociencias, 16(3), 156-161.

16. Principales causas de mortalidad por residencia habitual, grupos de edad y sexo del fallecido [Internet]. México: INEGl; 2015. Disponible en: http:// wwwinegiorgmx/est/contenidos/proyectos/registros/vitales/mortalidad/tabulados/ConsultaMortalidadasp.

17. Villatoro Velázquez J, Bustos Gamiño M, Oliva Robles N, Fregoso Ito D, Mujica Salazar A, Martín del Campo Sánchez R, et al. Encuesta Nacional de Consumo de Drogas en Estudiantes 2014: Reporte de Tabaco [Internet]. México: Instituto Nacional de Psiquiatría Ramón de la Fuente Muñiz México; 2015. Disponible en: https://wwwgobmx/cms/uploads/attachment/file/239258/ENCODE_TABACO_2014pdf.

18. Villatoro Velázquez J, Bustos Gamiño M, Oliva Robles N, Fregoso Ito D, Mujica Salazar A, Martín del Campo Sánchez R, et al. Encuesta Nacional de Consumo de Drogas en Estudiantes 2014: Reporte de Alcohol [Internet]. México: Instituto Nacional de Psiquiatría Ramón de la Fuente Muñiz México; 2014. Disponible en: https://wwwgobmx/cms/uploads/attachment/file/239257/ENCODE_ALCOHOL_2014pdf.

19. Villatoro-Velázquez J, Bustos Gamiño M, Oliva Robles N, Fregoso Ito D, Mujica Salazar A, Martín del Campo Sánchez R, et al. Encuesta Nacional de Consumo de Drogas en Estudiantes 2014: Reporte de Drogas [Internet]. México: Instituto Nacional de Psiquiatría Ramón de la Fuente Muñiz México; 2014. Disponible en: http://wwwconadicsaludgobmx/pdfs/ investigacion/ENCODE_DROGAS_2014pdf.

20. Santoyo Castillo D, Frías SM. Acoso escolar en México: actores involucrados y sus características. 2014.

21. Márquez-Caraveo ME, Arroyo-García E, Granados-Rojas A, Ángeles-Llerenas AJ. Hospital Psiquiátrico Infantil Dr. Juan N. Navarro: 50 años de atención a la salud mental de niños y adolescentes en México. 2017;59:477-84.

22. Sauceda García JM. Trastorno por déficit de atención con hiperactividad: un problema de salud pública. 2014;57:14-9.

23. Grotberg E. A guide to promoting resilience in children: strengthening the human spirit [Internet]. La Haya, Países Bajos: Bernard Van Leer Foundation; 1995. Disponible en: https://bibalexorg/baifa/Attachment/ Documents/115519pdf

24. Gil GE. La resiliencia: conceptos y modelos aplicables al entorno escolar. 2010;19:27-42.

25. Vilar J, Pont EJ. Reflexiones en torno a la resiliencia. Una conversación con Stefan Vanistendael. 2009:93-103.

26. Windle GJ. What is resilience? A review and concept analysis. 2011;21:152-69.

27. Louro Bernal IJ. La familia en la determinación de la salud. 2003;29:48-51.

28. Ternera LA. El desarrollo del autoconcepto en niños y niñas y su relación con la interacción social en la infancia. 2014:17:67-9.

29. Isaza-Valencia L, Henao-López CG. Influencia del clima sociofamiliar y estilos de interacción parental sobre el desarrollo de habilidades sociales en niños y niñas. 2012:253-71.

30. Cuervo Martinez Á. Pautas de crianza y desarrollo socioafectivo en la infancia. 2010;6.

31. Mangrulkar L, Whitman CV, Posner M. Enfoque de habilidades para la vida para un desarrollo saludable de niños y adolescentes Washington, DC: OPS; 2001

32. Fuentes MC, Alarcón A, García F, Gracia EJ. Consumo de alcohol, tabaco, cannabis y otras drogas en la adolescencia: efectos de la familia y peligro del barrio. 2015;31:1000-7.

33. Ramírez Ruiz M, de Andrade DJ. La familia y los factores de riesgo relacionados con el consumo de alcohol y tabaco en los niños y adolescentes (Guayaquil-Ecuador). 2005;13.

34. Gallegos WL. Agresión y violencia en la adolescencia: La importancia de la familia. 2013;21:23-34

35. Jiménez JSFG, Serrano MdLPJU. Desensibilización a la violencia una revisión teórica para la delimitación de un constructo. 2017;11:70-81.

36. UNICEF. Desarrollo psicosocial de los niños y las niñas. 2. ㄹ Ed [Internet]. UNICEF, Oficina de Área para Colombia y Venezuela; 2004. Disponible en: https://wwwuniceforg/colombia/pdf/ManualDPpdf

37. Promoción de la Salud: Glosario [Internet]. México: Ministerio de Sanidad y Consumo; 1998. Disponible en: https://wwwmsssigobes/profesionales/ saludPublica/prevPromocion/docs/glosariopdf

38. NIGZ, Centro Colaborador de la OMS para la Promoción de la Salud Escolar. Red de Escuelas para la Salud en Europa, red SHE. Coordina-ción en España. 2017.

39. Derechos Humanos. Convención sobre los Derechos de los Niños [Internet]. Organización de las Naciones Unidas; fecha. Disponible en: http://www.ohchr.org/SP/Professionallnterest/Pages/CRC.aspx

40. Jourdan D, Mannix McNamara P, Simar C, Pommier J. Factors influencing the contribution of staff to health education in schools. Health Educ Res. 2010;25(4):519-30. 


\section{Gaceta Médica de México. 2019;155(Suppl 1)}

41. Fondo de las Naciones Unidas para la Infancia UNICEF. Convención sobre los derechos de los niños. 4a Ed. México. 2002. Disponible: http:// sitios.dif.gob.mx/difusoresnacionales/wp-content/uploads/2015/10/ConvencionDerechosNinos.pdf

42. Patino-Fernández AM, Hernández J, Villa M, Delamater A. School-based health promotion intervention: parent and school staff perspectives. J Sch Health. 2013;83:763-70.

43. Ramos P, Pasarín Ml, Artazcoz L, et al. Escuelas saludables y participativas: evaluación de una estrategia de salud pública. Gac Sanit. 2013; $27: 104-10$
44. Jourdan D, Pironom J, Berger D, et al. Factors influencing teachers' views of health and health education: a study in 15 countries. Health Educ J. 2013;72:660-72.

45. Bronfenbrenner U, Morris PA. The bioecological model of human development. En: Lerner RM, editor. Handbook of child psychology. Vol. 1. Theoretical models of human development. Hoboken, NJ: John Wiley \& Sons; 2006. pp. 793-828.

46. Pérez GA. Paradigmas contemporáneos de investigación didáctica, en Gimeno SJ y Perez GA. La enseñanza: su teoría y su práctica, Madrid: Akal editor. 1985 pp. $125-138$. 